\title{
ASCIDIA PEDUNCULATA.
}

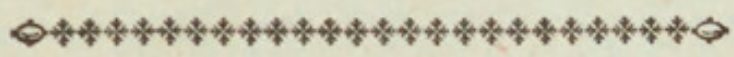

CHARACTER GENERICUS.

Corpus fixum, teretiufculum, vaginans. Aperture binæ ut plurimum ad fummitatem.

$$
\text { Lin. Syf. Nat. Gmel. p. } 3127 .
$$

CHARACTER SPECIFICUS, छC.

ASCIDIA ftipite longiffimo, capitulo ovato, apertura utraque terminali.

ASCIDIA ftipite fenfim attenuato, capitulo fufiformi, apertura utraque terminali.

Lin. Syft Nat. Gmel. p. 3I 27 .

VORTICELLA OVIFERA.

Lin. Syft. Nat. Edit. 12. p. 1319.

Afcidiam clavatam, qua rariorem nullam continet genus, in hoc opere antea defcripfimus. Species de qua jam agitur, licet illi valde fit affinis, non modo corpus habet multo rotundius, fed et foramina ambo terminalia, feu non in lateribus fita. Corpus fubrubrum et læve. Stipes fufco-rubet, fcaber, fetulis parvulis feu fpiculis obfitus. Maria incolit Septentrionalia Afcidia pedunculata, rupibus, lapidibus, conchifque majoribus plerumque affixa. 




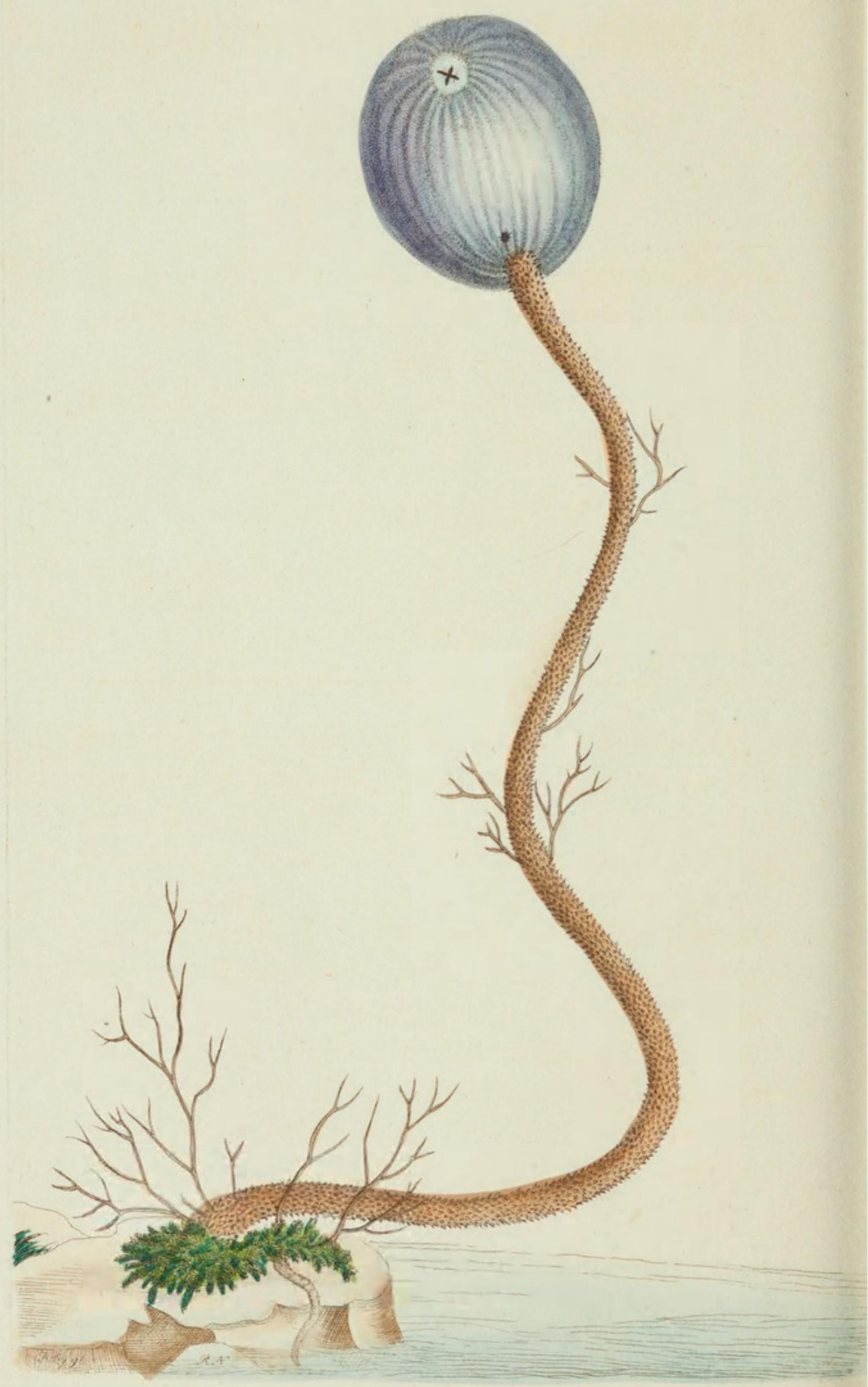




\section{PEDUNCULATED ASCIDIA.}

Q

GENERIC CHARACTER.

Body fixed, approaching more or lefs to a cylindric thape; in fome fpecies feffile; in others fupported on a pedicle. Apertures in moft fpecies two: fituated towards the upper part.

SPECIFIC CHARACTER.

LONG-STALKED ASCIDIA with oval body and two terminal apertures.

The Afcidia clavata, one of the rareft and moft curious animals of its genus, has already been defcribed in the prefent work. The fpecies now reprefented is much allied to it in general appearance, but differs in the fhape of the body, which is much rounder, and in the fituation of the apertures, which are terminal inftead of lateral, as in the former animal. The body is of a reddifh color, and fmooth: the ftem of a darker red, and rough, or befet with minute briftles or fpicula. It is a native of the Northern feas, and is generally found affixed either to ftones, rocks, or large fhells. 


\section{$2 \mathrm{BHL}$ Biodiversity Heritage Library}

Shaw, George. 1795. "Pedunculated Ascidia, Ascidia pedunculata [PI. 239]." The Naturalist's Miscellany 7(LXXV), https://doi.org/10.5962/p.310782.

View This Item Online: https://www.biodiversitylibrary.org/item/276356

DOI: https://doi.org/10.5962/p.310782

Permalink: https://www.biodiversitylibrary.org/partpdf/310782

\section{Holding Institution}

Museums Victoria

\section{Sponsored by}

Atlas of Living Australia

\section{Copyright \& Reuse}

Copyright Status: Public domain. The BHL considers that this work is no longer under copyright protection.

This document was created from content at the Biodiversity Heritage Library, the world's largest open access digital library for biodiversity literature and archives. Visit BHL at https://www.biodiversitylibrary.org. 